\title{
Textural and Petrographic Characterization of the Soil of Amtiman (South-East Chad)
}

\author{
Al-hadj Hamid ZAGALO ${ }^{1,2}$, Maurice KWEKAM ${ }^{1}$, François NGAPGUE ${ }^{1,3}$ \& Idriss Goudja TCHERE ${ }^{4}$ \\ ${ }^{1}$ Université de Dschang, Faculté des Sciences, B.P. 67 Dschang, Cameroun \\ ${ }^{2}$ Université des Sciences et de Technologie d'Ati, Faculté des Sciences de la vie, de la Terre et de l'Aménagement \\ du Territoire - Ati, Tchad \\ ${ }^{3}$ Université de Dschang, Institut Universitaire de Technologie Fotso Victor - Bandjoun, Cameroun \\ ${ }^{4}$ Laboratoire de Génie Civil - N'djaména, Tchad \\ Correspondence: Maurice Kwékam, Université de Dschang, B. P. 67 Dschang, Cameroun. Tel: 237-677-516-684. \\ E-mail: maurice.kwekam@univ-dschang.org/mkwekam@yahoo.fr/filsbenbadour@yahoo.fr
}

Received: October 16, 2017

Accepted: October 29, 2017

Online Published: November 25, 2017

doi:10.5539/esr.v7n1p67

URL: https://doi.org/10.5539/esr.v7n1p67

\begin{abstract}
The textural and petrographic characteristics of the soils of the city of Amtiman and their behavior on swelling and shrinkage are presented here.

The soils of the town of Amtiman (Chad) have a predominantly clay texture and the clays are mainly exposed on the surface. The results of this work include characterizing the type of clay present in the city. These are the heterogeneous layers of clayey soils consisting mainly of surface-bound illites but also of kaolinite intercalation at depth.

These results suggest that the phenomenon of shrinkage of the clays (Illite and kaolinite) of the city of Amtiman is very low and that this city belongs to the sedimentary basin of Salamat.

Keywords: Amtiman, Chad, characterization, clays, illite, kaolinite, low absorbent

\section{Introduction}

A good knowledge of the textural and petrographic properties of soils allows us to understand the geological context and their behavior in various applications. Geological surveys in the town of Amtiman, the chief place of the Salamat region, are almost absent and not detailed except for the geological reconnaissance map of Chad (Fig.1). The present study was initiated in order to contribute to the textural and petrographic characterization of the soil of the city. It consisted of carrying out analyzes on soil samples of the city of Amtiman at the Laboratory of the International University of Africa in the Republic of Sudan.
\end{abstract}




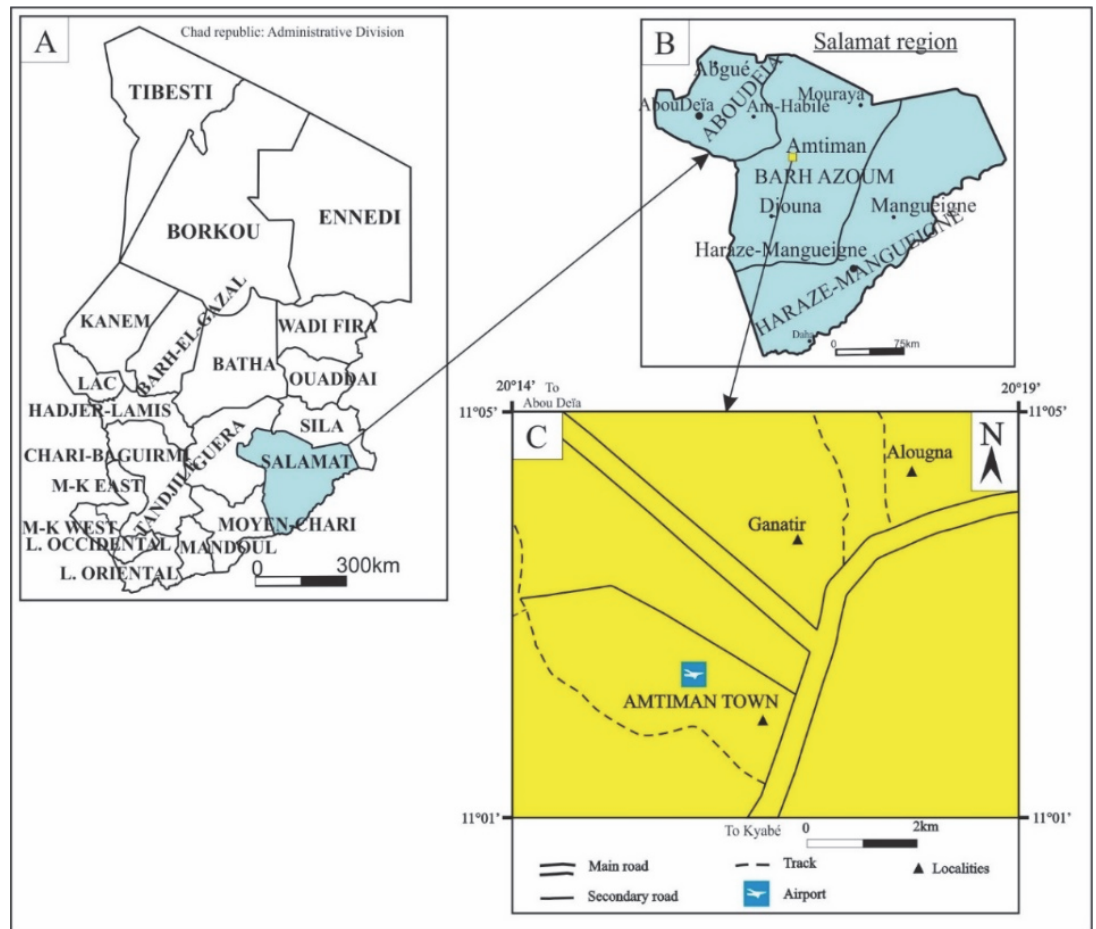

Figure 1. Location map of the study area. (Extracted from the Chad Administrative Division map and communication channels at the scale of 1/7 000000 INSEED, 2009). A: Map of Chad. B: Map of the Salamat region. C: Study area

\section{METHODOLOY}

\subsection{Location of Study Sites and Sampling}

In order to have representative samples of the city, the sites were chosen in different parts of the city (Fig. 2). The sampling was carried out by core sampling (Fig. 3). The reworked samples (Fig. 4) were used for mineralogical and textural analyzes.

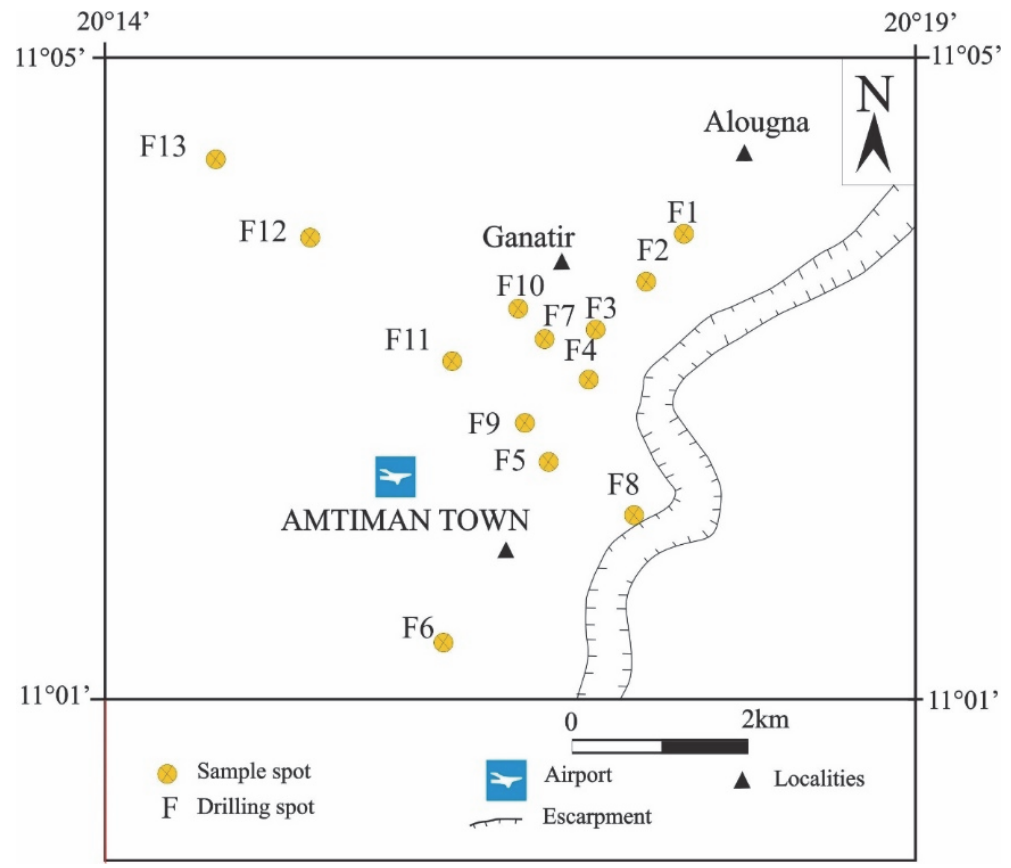

Figure 2. Sampling map 


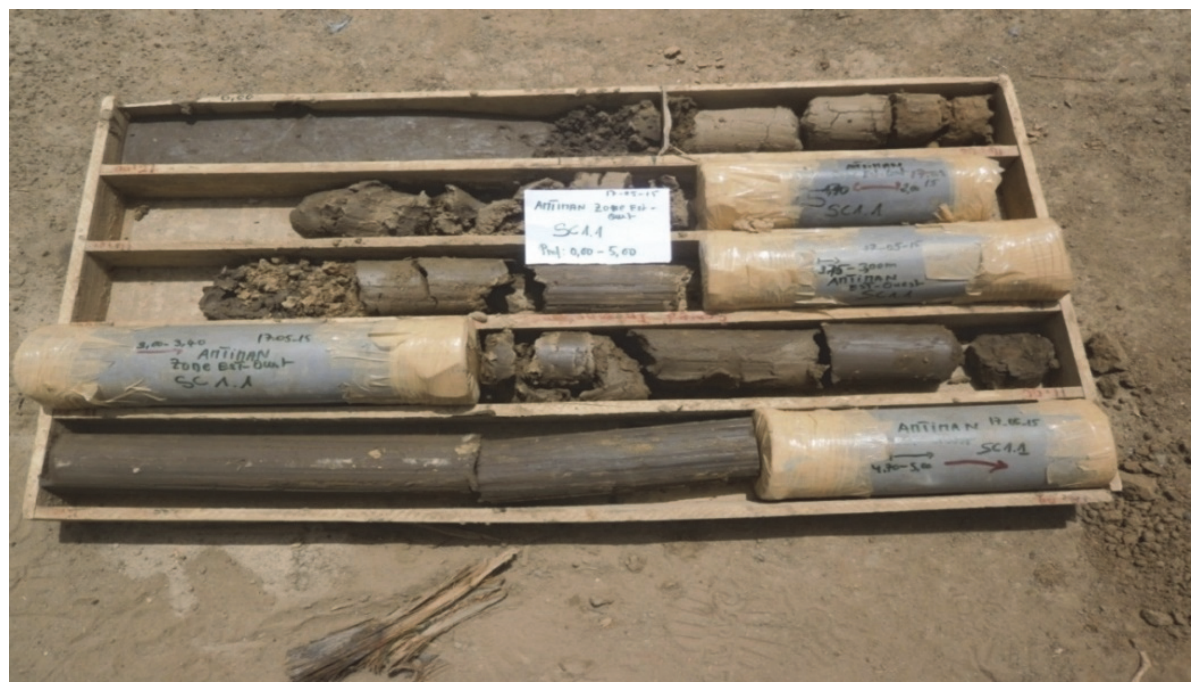

Figure 3. Clay samples from drilling

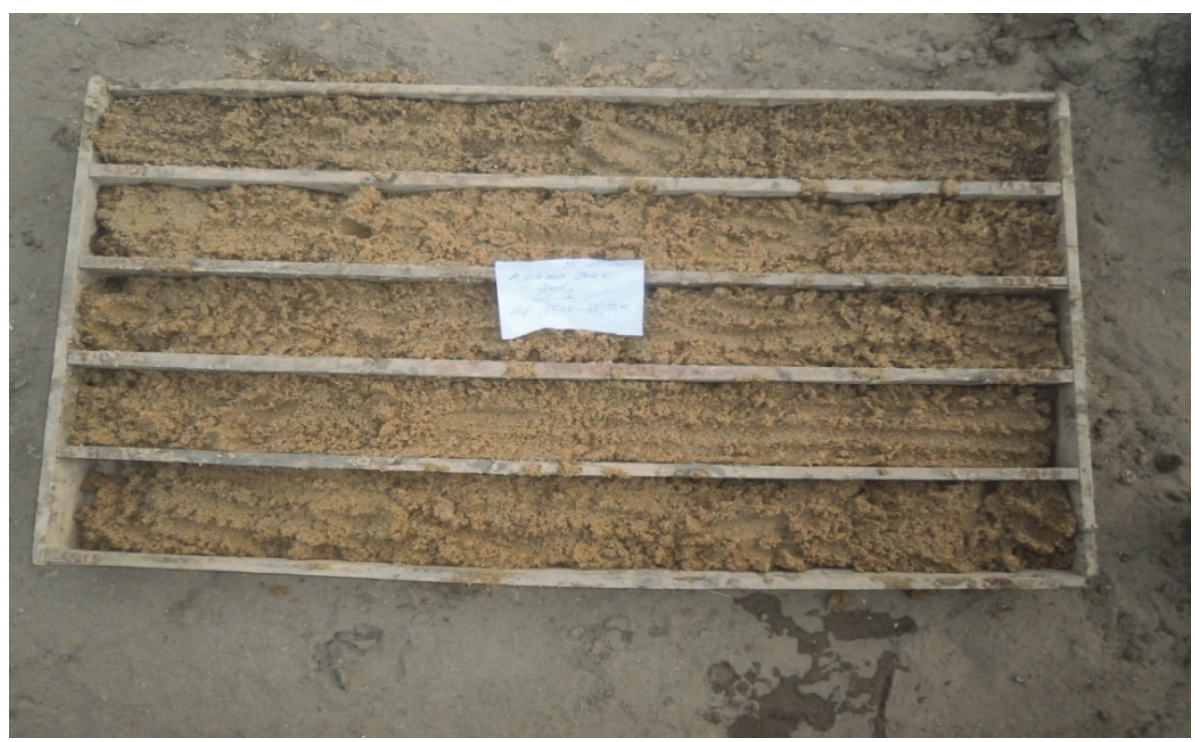

Figure 4. Samples of sand from drilling

\subsection{Experimentation}

The petrographic study was carried out by the macroscopic description of the sequences (Fig. 5).

The texture of the soil studied was determined according to the following procedure:

42 grams of soil dried for 72 hours previously passed through a $2 \mathrm{~mm}$ sieve, to which $50 \mathrm{ml}$ of sodium hexametaphosphate $\left(\mathrm{NaPO}_{3}\right)_{6}$ are added, are introduced into a glass tube. The mixture is allowed to stand for ten minutes. This mixture is then introduced into the tube of the electric stirrer and kneaded for at least 5 minutes. The kneaded material is introduced into a $1000 \mathrm{ml}$ test piece and distilled water is added to the $1000 \mathrm{ml}$ graduation; the whole is stirred with a mechanical stirrer for 10 strokes. In addition, a control sample consisting solely of sodium hexametaphosphate $\left(\mathrm{NaPO}_{3}\right)_{6}$ and distilled water is prepared. Reading is carried out after 40 seconds for the preparation as well as for the control by means of a densimeter and the corresponding temperature is taken with the aid of a thermometer. A second reading is made after 2 hours.

The percentage determination of particles is made by the following formulas:

$$
\mathrm{R}_{1}=\frac{(\mathrm{Lm} 1-\mathrm{Lt} 1) \pm\left(\mathrm{T}^{\circ}-19,4\right) 0,36}{\mathrm{Msec}} \times 100 \text { and } \mathrm{R}_{2}=\frac{(\mathrm{Lm} 2-\mathrm{Lt} 2) \pm\left(\mathrm{T}^{\circ}-19,4\right) 0,36}{\mathrm{Msec}} \times 100
$$

Where $\mathrm{Lm} 1$ and $\mathrm{Lm} 2$ designate the reading of the preparation after 40 seconds and 2 hours respectively; 
Lt1 and Lt2 respectively indicate the reading of the control after 40 seconds and 2 hours;

$\mathrm{T}^{\circ}$ temperature at $40 \mathrm{~s}$ and at 2 hours depending on the case; 19.4: Temperature of the hydrometer; 0.36 : conventional temperature factor; Msec: Mass of the sample in the dry state.

$$
\text { With R1 = clay + silt; R2 = Clay and Sand }=100-\text { R1 }
$$

The percentages of the silts, sands and clays obtained are plotted in the textural classification diagram. The classification used is that of WRB (FAO, 2006) which defines thirteen (13) texture classes according to the relative proportions of sand, silt and clay (Table 2 and Fig. 6).

The mineralogical composition obtained by the X-ray diffraction analysis was carried out only on the fine fraction obtained by decantation. The X-ray diffraction devise is Philips type operating at $40 \mathrm{kv}$ and $50 \mathrm{~mA}$. It is connected to a computer that directly gives the diffractogram. The analysis of the diffractogram is done using the X'PERT DATA VIEWER software. The results are shown in Table 1.

\section{Results and Discussion}

\subsection{Macroscopic Description of the Sequences}

The soils of the study area have heterogeneous layers as a function of depth. Two representative sequences have been chosen and presented in figure 5 .

The lithology of borehole 6 (Fig.5a) has six (6) levels from top to bottom:

- level 1: layer of brown clay, one (1) $\mathrm{m}$ thick from 0 to $1 \mathrm{~m}$ deep;

- level 2: gray to green clay, one (1) $\mathrm{m}$ thick from 1 to $2 \mathrm{~m}$ deep;

- level 3: clayey layer, black in color, $3 \mathrm{~m}$ thick, from 2 to $5 \mathrm{~m}$ deep;

- level 4: brown clay with a thickness of $4 \mathrm{~m}$ ranging from 5 to $9 \mathrm{~m}$ deep;

- level 5: sandy clay, the thickness of which is $3 \mathrm{~m}$, from 9 to $12 \mathrm{~m}$ deep;

- level 6: sandy layer with mixed grains, $8 \mathrm{~m}$ thick from 12 to $20 \mathrm{~m}$ deep;

The lithology of borehole 8 (Figure $5 \mathrm{~b}$ ) also shows six (6) levels from top to bottom:

- level 1: clayey layer, gray in color, $3 \mathrm{~m}$ thick, ranging from 0 to $3 \mathrm{~m}$ deep;

- level 2: clay layer, black in color, $4 \mathrm{~m}$ thick, 3 to $7 \mathrm{~m}$ deep;

- level 3: clayey layer, gray in color, $3 \mathrm{~m}$ thick ( 7 to $10 \mathrm{~m}$ ) deep;

- level 4: sandy clay, $4 \mathrm{~m}$ thick, ranging from 10 to $14 \mathrm{~m}$ deep;

- level 5: sandy coarse layer, with a thickness of $2 \mathrm{~m}$ and a depth of 14 to $16 \mathrm{~m}$;

- level 6: sandy layer with mixed grains, $4 \mathrm{~m}$ thick, ranging from 16 to $20 \mathrm{~m}$ deep.
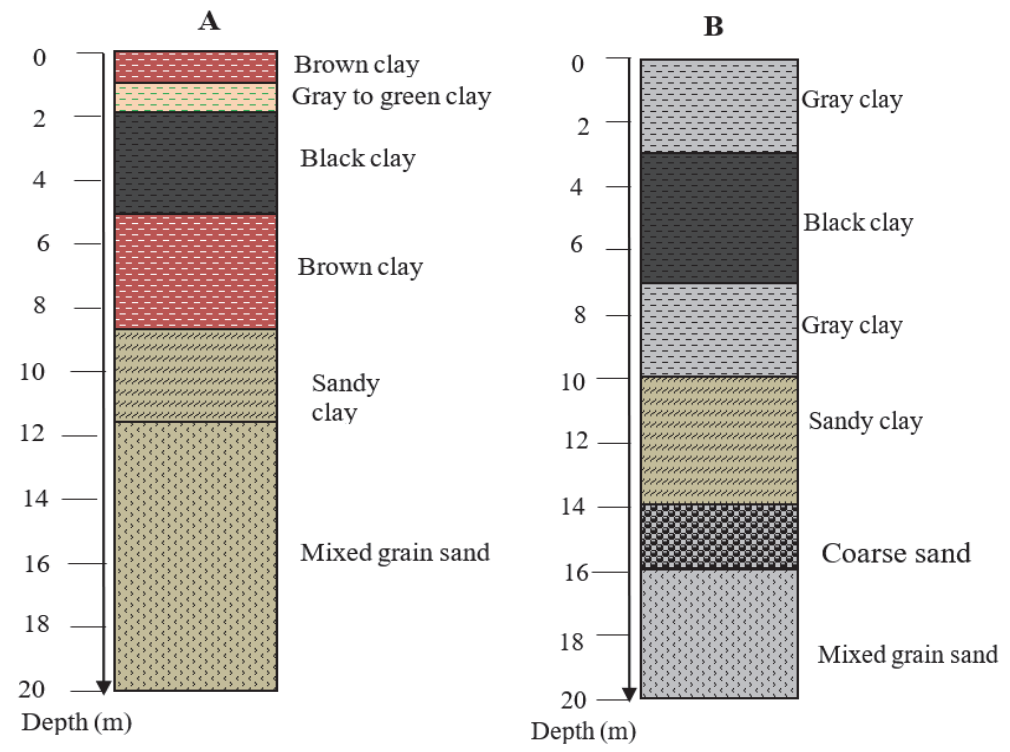

Figure 5. Lithological logs. A: Drilling 6; B: Drilling 8

This description shows that the soil has heterogeneous layers in most of the boreholes. This agrees with the 
description of Boudlal Omar (2013).

\subsection{Mineralogy}

The mineralogical analysis of the fine fraction carried out on twenty (20) samples reveals that the minerals identified are in decreasing order of abundance: illite, kaolinite, interstratified, chlorite and smectite. These results are summarized in Table 1. The results obtained are consistent with the study by Berezantsev et al. (1961) which shows that the most prevalent minerals are kaolinite, montmorillonite and illite. The illite abundance of these soils shows their low absorptive capacity as well as swelling. The kaolinite and illite clays are relatively more stable with respect to their adsorption and absorption capacity (Eslinger et Peaver, 1988). Likewise, they are stable clays with a swelling-shrinkage effect, and can thus be used in the foundations of dwellings (Parker et Rae, 19890; Maison, 2011). The difference in cation exchange capacity values of kaolinite and illite is small (Laribi et al., 2009).

Table 1. Mineralogical Composition of Amtiman fine soils

\begin{tabular}{llllllll}
\hline $\mathrm{N}^{\circ}$ & Sample & $\begin{array}{l}\text { Depth (m) } \\
(\mathrm{m})\end{array}$ & $\begin{array}{l}\text { Kaolinite (\%) } \\
(\%)\end{array}$ & $\begin{array}{l}\text { Smectite (\%) } \\
(\%)\end{array}$ & $\begin{array}{l}\text { Illite (\%) } \\
(\%)\end{array}$ & $\begin{array}{l}\text { Chlorite (\%) } \\
(\%)\end{array}$ & $\begin{array}{l}\text { Smectite/Illite (\%) } \\
(\%)\end{array}$ \\
\hline 1 & F1c & $1-2.5$ & 19.62 & 0.08 & 80.10 & 0.12 & 0.08 \\
2 & F2a & $0-1$ & 12.88 & 0.09 & 86.79 & 0.14 & 0.09 \\
3 & F2b & $1-2$ & 24.33 & 0.08 & 71.13 & 0.12 & 4.34 \\
4 & F3a & $0-3$ & 18.71 & 0.10 & 77.52 & 0.15 & 3.51 \\
5 & F3c & $4-9$ & 28.63 & 0.13 & 70.93 & 0.19 & 0.13 \\
6 & F4a & $0-1,35$ & 24.33 & 0.07 & 75.42 & 0.11 & 0.07 \\
7 & F4f & $5-6$ & 93.81 & 0.79 & 3.44 & 1.17 & 0.79 \\
8 & F5b & $1-2$ & 19.62 & 0.08 & 80.10 & 0.12 & 0.08 \\
9 & F5d & $3-4$ & 92.75 & 0.93 & 4.03 & 1.37 & 0.93 \\
10 & F5h & $7-8$ & 95.19 & 0.61 & 2.67 & 0.91 & 0.61 \\
11 & F6h & $9-12$ & 96.88 & 0.40 & 1.73 & 0.59 & 0.40 \\
12 & F7f & $7-11$ & 94.93 & 0.65 & 2.82 & 0.96 & 0.65 \\
13 & F9b & $2-3$ & 21.25 & 0.11 & 78.37 & 0.16 & 0.11 \\
14 & F10c & $4-5$ & 34.28 & 0.12 & 65.31 & 0.18 & 0.12 \\
15 & F11a & $0-1$ & 26.56 & 0.07 & 73.21 & 0.10 & 0.07 \\
16 & F11b & $1-2$ & 21.61 & 0.07 & 78.13 & 0.11 & 0.07 \\
17 & F12a & $0-2$ & 14.36 & 0.12 & 85.23 & 0.17 & 0.12 \\
18 & F12b & $2-5$ & 13.55 & 0.06 & 86.23 & 0.10 & 0.06 \\
19 & F13a & $0-1$ & 16.83 & 0.06 & 82.96 & 0.09 & 0.06 \\
20 & F13c & $2.65-4$ & 17.30 & 0.07 & 82.45 & 0.10 & 0.07 \\
\hline
\end{tabular}

These results do not agree with those of Gourouza et al. (2003), according to which the mixed clays of Niger consist of $34 \%$ montmorillonite, $24 \%$ kaolinite, $17 \%$ illite and $25 \%$ interstratified illite / smectite.

\subsection{Textural Classification}

Physical parameters are used to characterize a soil on the physical plane. The classification is generally used for fine soils whose particles are classified according to their dimensions into three (03) fractions: sand, silt and clay. Indeed, clays are very abundant in nature and cover about $42 \%$ of the volume of the Earth's crust (Wakim, 2005; Qlihaa et al., 2016).

The WRB classification (FAO, 2006) defines thirteen (13) texture classes according to the relative proportions of sand, silt and clay. These are loamy clays, clays, silty clays, sandy clays, clay loams, fine clay loams, sandy clay loams, silts, fine silts, very fine silts, sandy loams, silty sands, sand. Each texture class defines a range in a triangular diagram whose vertices are occupied by clay, silt and sand and is called a textural triangle (Fig. 6). After physical analysis of a soil, its textural class is determined by projecting the relative proportions of each fraction into the textural triangle.

Ninety-eight (88) samples from 13 boreholes were analyzed and the results are shown in Table 2. 
Table 2. Fine particle size distribution of clay materials.

\begin{tabular}{|c|c|c|c|c|}
\hline Samples & Clay $(\%)$ & Silt (\%) & Sand $(\%)$ & WRB Classification \\
\hline \multicolumn{5}{|c|}{ Borehole 1} \\
\hline F1b & 53.14 & 35.00 & 11.86 & Clay \\
\hline F1c & 53.14 & 35.00 & 11.86 & Clay \\
\hline F1d & 45.64 & 38.00 & 15.61 & Clay \\
\hline F1f & 61.89 & 8.75 & 29.36 & Clay loam \\
\hline F1g & 59.39 & 15.61 & 25.00 & Clay \\
\hline F1h & 51.89 & 13.75 & 34.36 & Clay \\
\hline \multicolumn{5}{|c|}{ Borehole 2} \\
\hline $\mathrm{F} 2 \mathrm{a}$ & 26.89 & 21.25 & 51.86 & Sandy clay loam \\
\hline $\mathrm{F} 2 \mathrm{~b}$ & 40.64 & 47.50 & 11.86 & Fine clay loam \\
\hline $\mathrm{F} 2 \mathrm{c}$ & 39.39 & 52.50 & 8.11 & Fine clay loam \\
\hline $\mathrm{F} 2 \mathrm{c}$ & 46.89 & 41.50 & 11.86 & Loam clay \\
\hline $\mathrm{F} 2 \mathrm{~d}$ & 81.89 & 6.25 & 11.86 & Clay loam \\
\hline $\mathrm{F} 2 \mathrm{e}$ & 83.14 & 5.00 & 11.86 & Clay loam \\
\hline \multicolumn{5}{|c|}{ Borehole 3} \\
\hline F3a & 29.74 & 41.25 & 29.01 & Loam clay \\
\hline F3a & 42.24 & 40.00 & 17.76 & Loam clay \\
\hline F3a & 25.99 & 26.25 & 47.76 & Sandy clay loam \\
\hline $\mathrm{F} 3 \mathrm{~b}$ & 50.99 & 45.00 & 4.01 & Clay loam \\
\hline F3c & 70.99 & 10.00 & 19.01 & Loam clay \\
\hline $\mathrm{F} 3 \mathrm{c}$ & 67.24 & 15.00 & 17.76 & Loam clay \\
\hline F3c & 57.24 & 26.25 & 16.51 & Clay \\
\hline \multicolumn{5}{|c|}{ Borehole 4} \\
\hline $\mathrm{F} 4 \mathrm{a}$ & 39.04 & 30.00 & 30.96 & Clay loam \\
\hline $\mathrm{F} 4 \mathrm{~b}$ & 32.79 & 23.75 & 43.46 & Clay loam \\
\hline $\mathrm{F} 4 \mathrm{~d}$ & 80.29 & 18.75 & 0.96 & Loam clay \\
\hline $\mathrm{F} 4 \mathrm{e}$ & 86.89 & 1.25 & 11.86 & Loam clay \\
\hline F4f & 86.89 & 1.25 & 11.86 & Loam clay \\
\hline $\mathrm{F} 4 \mathrm{~g}$ & 85.29 & 13.75 & 0.96 & Loam clay \\
\hline $\mathrm{F} 4 \mathrm{H}$ & 86.89 & 1.25 & 11.86 & Loam clay \\
\hline $\mathrm{F} 4 \mathrm{i}$ & 64.04 & 10.00 & 25.96 & Loam clay \\
\hline $\mathrm{F} 4 \mathrm{j}$ & 64.04 & 5.00 & 30.96 & Loam clay \\
\hline \multicolumn{5}{|c|}{ Borehole 5} \\
\hline F5a & 69.74 & 26.25 & 4.01 & Loam clay \\
\hline $\mathrm{F} 5 \mathrm{~b}$ & 47.04 & 25.00 & 27.96 & Clay \\
\hline F5c & 72.24 & 18.75 & 9.01 & Loam clay \\
\hline F5d & 69.74 & 22.50 & 7.76 & Loam clay \\
\hline $\mathrm{F} 5 \mathrm{e}$ & 72.24 & 23.75 & 4.01 & Loam clay \\
\hline F5f & 67.04 & 26.25 & 6.71 & Loam clay \\
\hline F5g & 72.24 & 23.75 & 4.01 & Loam clay \\
\hline F5h & 54.54 & 12.50 & 32.96 & Clay \\
\hline F5i & 54.74 & 21.25 & 24.01 & Clay \\
\hline $\mathrm{F} 5 \mathrm{j}$ & 59.54 & 17.50 & 22.96 & Clay \\
\hline \multicolumn{5}{|c|}{ Borehole 6} \\
\hline F6a & 54.54 & 38.75 & 6.71 & Clay \\
\hline F6b & 54.54 & 27.50 & 17.96 & Clay \\
\hline F6d & 70.79 & 18.75 & 10.46 & Loam clay \\
\hline F6e & 67.04 & 26.25 & 6.71 & Loam clay \\
\hline F6f & 67.04 & 22.50 & 10.46 & Loam clay \\
\hline F6h & 34.54 & 15.00 & 50.46 & Sandy clay loam \\
\hline F6h & 39.54 & 17.50 & 42.96 & Clay loam \\
\hline \multicolumn{5}{|c|}{ Borehole 7} \\
\hline F7a & 36.54 & 62.50 & 0.96 & Fine clay loam \\
\hline
\end{tabular}




\begin{tabular}{|c|c|c|c|c|}
\hline Samples & Clay $(\%)$ & Silt $(\%)$ & Sand $(\%)$ & WRB Classification \\
\hline F7a & 56.54 & 30.00 & 13.46 & Clay \\
\hline F7a & 36.54 & 45.00 & 18.46 & Fine clay loam \\
\hline F7b & 81.54 & 17.50 & 0.96 & Loam clay \\
\hline F7c & 81.54 & 17.50 & 0.96 & Loam clay \\
\hline F7d & 72.79 & 13.75 & 13.46 & Loam clay \\
\hline F7e & 44.04 & 25.00 & 30.96 & Clay \\
\hline F7e & 44.04 & 25.00 & 30.96 & Clay \\
\hline \multicolumn{5}{|c|}{ Borehole 8} \\
\hline F8a & 52.04 & 35.00 & 12.96 & Clay \\
\hline F8a & 32.04 & 50.00 & 17.96 & Fine clay loam \\
\hline $\mathrm{F} 8 \mathrm{~b}$ & 73.29 & 21.25 & 5.46 & Loam clay \\
\hline $\mathrm{F} 8 \mathrm{c}$ & 77.04 & 17.50 & 5.46 & Loam clay \\
\hline F8d & 73.29 & 18.75 & 7.96 & Loam clay \\
\hline F8f & 55.64 & 20.00 & 24.36 & Clay \\
\hline \multicolumn{5}{|c|}{ Borehole 9} \\
\hline F9a & 35.64 & 57.50 & 6.86 & Fine clay loam \\
\hline F9a & 25.64 & 42.50 & 31.86 & Silt \\
\hline F9b & 64.39 & 31.25 & 4.36 & Loam clay e \\
\hline F9c & 65.64 & 25.00 & 9.36 & Loam clay \\
\hline F9c & 64.39 & 31.25 & 4.36 & Loam clay \\
\hline F9e & 18.14 & 64.00 & 16.86 & Fine silt \\
\hline F9e & 25.64 & 42.50 & 31.86 & Silt \\
\hline \multicolumn{5}{|c|}{ Borehole 10} \\
\hline F10a & 34.04 & 65.00 & 0.96 & Fine clay loam \\
\hline F10a & 65.29 & 23.75 & 10.96 & Loam clay \\
\hline F10b & 66.54 & 12.50 & 20.96 & Loam clay \\
\hline F10c & 64.04 & 15.00 & 20.96 & Loam clay \\
\hline F10d & 30.29 & 12.50 & 57.21 & Sandy clay loam \\
\hline \multicolumn{5}{|c|}{ Borehole 11} \\
\hline F11a & 70.29 & 21.25 & 8.46 & Loam clay \\
\hline F11b & 34.04 & 26.25 & 39.71 & Clay loam \\
\hline F11c & 28.14 & 13.75 & 58.11 & Sandy clay loam \\
\hline F11e & 39.04 & 17.50 & 43.46 & Clay loam \\
\hline \multicolumn{5}{|c|}{ Borehole 12 } \\
\hline F12a & 38.14 & 8.75 & 53.11 & Sandy clay \\
\hline F12a & 28.14 & 11.25 & 60.61 & Sandy clay loam \\
\hline F12b & 20.64 & 13.75 & 65.61 & Sandy clay loam \\
\hline $\mathrm{F} 12 \mathrm{c}$ & 35.64 & 3.75 & 60.61 & Sandy clay \\
\hline \multicolumn{5}{|c|}{ Borehole 13 } \\
\hline F13a & 62.79 & 30.00 & 7.21 & Loam clay \\
\hline F13b & 43.14 & 45.00 & 11.86 & Clay loam \\
\hline F13c & 30.29 & 33.75 & 35.96 & Clay loam \\
\hline F13c & 38.14 & 53.75 & 8.11 & Fine clay loam \\
\hline F13d & 26.54 & 10.00 & 63.46 & Sandy clay loam \\
\hline F13d & 22.79 & 13.75 & 63.46 & Sandy clay loam \\
\hline F13e & 22.79 & 1.25 & 75.96 & Sandy clay loam \\
\hline F13e & 20.64 & 7.50 & 71.86 & Sandy clay loam \\
\hline
\end{tabular}




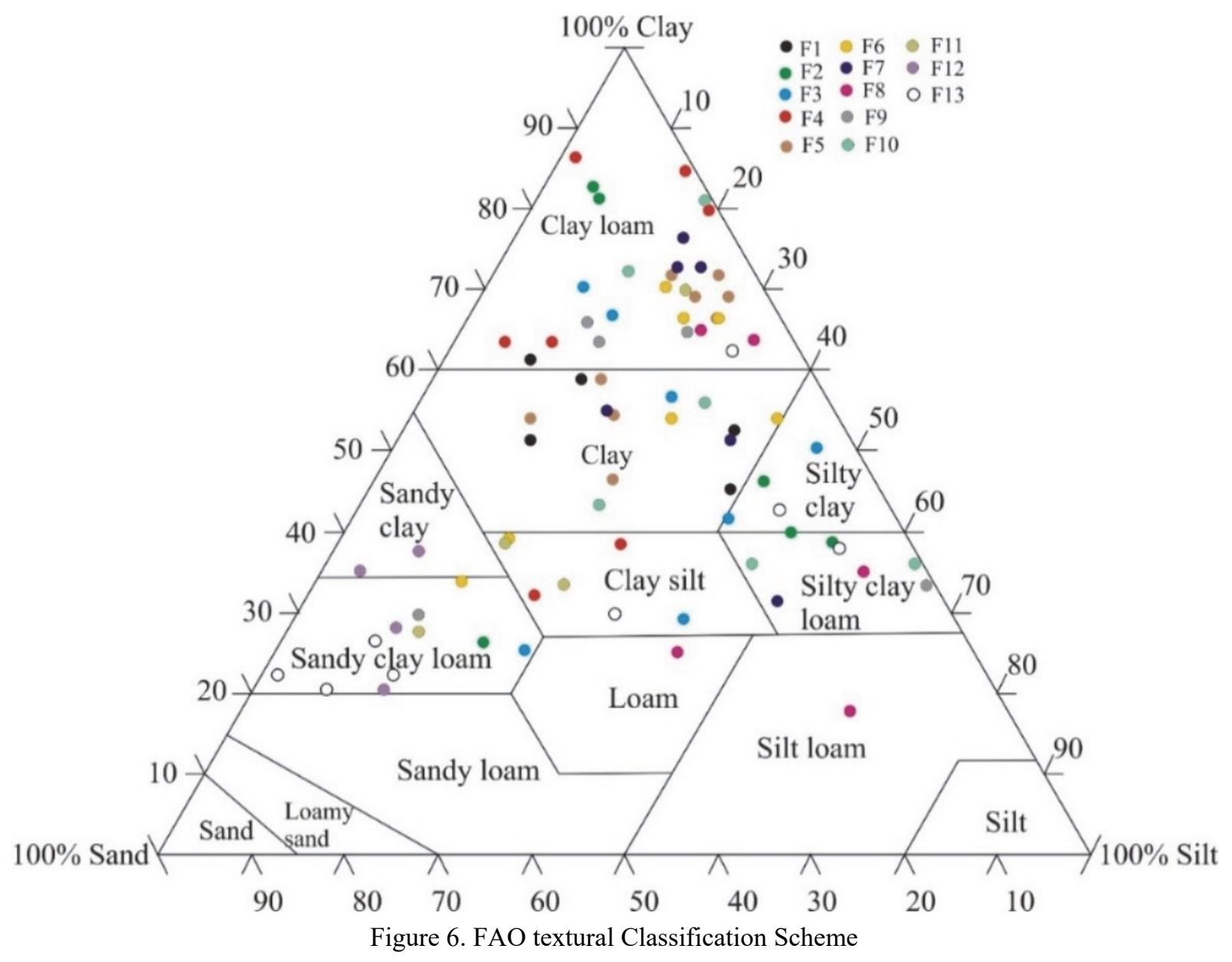

From the diagram in figure 6, the soil of the town of Amtiman consists largely of (more than 61\%) loam clay and clay. The presence of silty clay, clay loam, clayey-sandy clay, sandy clay, and silt and fine silt is also noted to a lesser extent. This confirms that the study area is a clay zone. Moreover, it has an insignificant percentage of fine silts and silts (Fig. 6).

\section{Conclusion}

The town of Amtiman the capital of the Salamat region in southeastern Chad, with more or less flat relief, has a Sahelo-Sudanese climate and mainly wooded vegetation. The present work shows that the soil of this city belongs to a large part to the class of fine soils, from clays to illite and kaolinite, mostly plastic to very plastic, with a degree of settlement that is more or less low, absorption. The soil of the town of Amtiman would be very inactive to the phenomenon withdrawal swelling. The use of this soil as a foundation requires a careful study of the mechanical characteristics in order to develop proposals for a rational dimensioning of the structures.

\section{Acknowledgements}

The authors thank Professor Mahamout Khayar and Doctor Mahamat Ali Mustapha for their scientific support.

\section{References}

Berezantsev, V. G., Kcenofontov, A. I., Platonov, E. V., Sidorov, N. N., \& Yaroshenko, V. A. (1961). Mécanique des sols et fondations (en russe : Mekhanika gruntov, osnovaniya i fundamenty). Moscou, Éditions du Ministère des Voies.

Boudlal, O. (2013). Etude expérimentale du comportement mécanique des fines dans la stabilité des talus et des fondations. Thèse doctorat, Université Mouloud Mammeri de Tizi- Ouzou, Algérie, 222p.

Eslinger, E., \& Peaver, D. (1988). Clay minerals for petroleum geologists and engineers, SEPM Short course 22. Soc. Economic paleontologists and mineralogists, Tulsa, USA.

Gourouza, M., Zanguina, A., Natatou, I., \& Boos, A. (2003). Caractérisation d'une argile mixte du Niger. Rev. 
CAMES-Sciences Struct. Mat., 1, 29-39.

Laribi, B., Bettaieb, I., Kouki, K., Sahli, A., Mougou, A., \& Marzouk, B. (2009). Water deficit effects on caraway growth, essential oil and fatty acid composition. Ind Crop Prod, 30, 372-379.

Maison, T. (2011). Analyse à l'échelle microscopique des phénomènes d'humectation et de dessiccation des argiles. Thèse Doctorat, Ecole Centrale des arts et manufactures. Ecole Centrale Paris, 271p.

Parker, \& Rae (1989). Environmental interactions of clays, clays and the environment. Springer UD8504/AR:AP.003.

Qlihaa, A., Dhimni, S., Melrhaka, F., Hajjaji, N., \& Srhiri, A. (2016). Caractérisation physico-chimique d'une argile marocaine. J. Mater. Environ. Sci., 7(5), 1741-1750.

Wakim, J. (2005). Influence des solutions aqueuses sur le comportement mécanique des roches argileuses. Thèse doctorat de l'Ecole Nationale Supérieure des Mines de Paris, France, 154p.

\section{Copyrights}

Copyright for this article is retained by the author(s), with first publication rights granted to the journal.

This is an open-access article distributed under the terms and conditions of the Creative Commons Attribution license (http://creativecommons.org/licenses/by/4.0/). 